\title{
High glucose-induced mesangial cell altered contractility: role of the polyol pathway
}

\author{
B. Derylo $^{1}$, T. Babazono ${ }^{2}$, E. Glogowski ${ }^{1}$, J.Kapor-Drezgic ${ }^{1}$, T.Hohman ${ }^{3}$, C. Whiteside $^{1}$ \\ ${ }^{1}$ Medical Research Council of Canada Group in Membrane Biology, Department of Medicine and Institute of Medical Science, \\ University of Toronto, Canada \\ 2 Tokyo Women's Medical College, Tokyo, Japan \\ ${ }^{3}$ Wyeth-Ayerst Research, Princeton, New Jersey, USA
}

\begin{abstract}
Summary Glomerular mesangial cells cultured in high glucose conditions display impaired contractile responsiveness. It was postulated that glucose metabolism through the polyol pathway leads to altered mesangial cell contractility involving protein kinase C. Rat mesangial cells were growth-arrested for $24 \mathrm{~h}$ with $0.5 \%$ fetal bovine serum in either normal $(5.6 \mathrm{mmol} / \mathrm{l})$ or high $(30 \mathrm{mmol} / \mathrm{l})$ glucose concentrations or high glucose plus the aldose reductase inhibitor, ARI-509 $(100 \mu \mathrm{mol} / \mathrm{l})$. The reduction of cell planar surface area (contraction) in response to endothelin-1 $(0.1 \mu \mathrm{mol} / \mathrm{l})$, or to phorbol 12-myristate 13acetate $(50 \mathrm{pmol} / \mathrm{l})$, was studied by videomicroscopy. In response to endothelin-1, mesangial cells in normal glucose contracted to $52 \pm 3 \%$ of initial planar area. In high glucose, the significantly $(p<0.05)$ smaller cell size and no contractile responsiveness to endothelin-1 were normalized with ARI-509. Membrane-associated diacylglycerol, measured by a kinase specific ${ }^{32} \mathrm{P}$-phosphorylation assay, in high glucose was unchanged after $3 \mathrm{~h}$, but significantly increased $(p<0.05)$ after $24 \mathrm{~h}$ which was normalized with ARI-509. Protein kinase $\mathrm{C}$ activity, measured
\end{abstract}

by in situ ${ }^{32} \mathrm{P}$-phosphorylation of the epidermal growth factor receptor substrate was: increased by $32 \%$ at $3 \mathrm{~h}$ of high glucose, unchanged by ARI-509; and decreased significantly $(p<0.05)$ at $24 \mathrm{~h}$ compared to cells in normal glucose, normalized by ARI-509. Total cellular protein kinase C-alpha, -delta and -epsilon, analysed by immunoblotting, were unchanged in high glucose at $24 \mathrm{~h}$. Only protein kinase C-epsilon content was reduced by ARI-509 in both normal and high glucose. Therefore, high glucose-induced loss of mesangial cell contractility, diacylglycerol accumulation and altered protein kinase $\mathrm{C}$ activity are mediated through activation of the polyolpathway, although no specific relationship between elevated diacylglycerol and protein kinase $\mathrm{C}$ activity was observed. In high glucose, altered protein kinase $\mathrm{C}$ function, or another mechanism related to the polyol pathway, contribute to loss of mesangial cell contractile responsiveness. [Diabetologia (1998) 41: 507-515]

Keywords Sorbitol, aldose reductase inhibitor, protein kinase $\mathrm{C}$, diacylglycerol.
Received: 18 July 1997 and in final revised form: 17 January 1998

Corresponding author: C. Whiteside, M.D., Ph.D., Medical Sciences Building, 7302, 1 King's College Circle, University of Toronto, Toronto, ON, Canada M5S 1 A8

Abbreviations: AA, Arachidonic acid; DMEM, Dulbecco's modified Eagle's medium; ET-1, endothelin-1; EGF, epidermal growth factor; FBS, fetal bovine serum; F, filamentous actin; DAG, diacylglycerol; PDD, phorbol 12, 13-didecanoate; PMA, phorbol 12-myristate 13-acetate; PA, phosphatidic acid; PL, phospholipase; PKC, protein kinase C -alpha (- $\alpha)$, -delta $(-\delta)$, epsilon $(-\varepsilon)$; STZ, streptozotocin; PBS, phosphate buffered saline.
Hyperglycaemia is necessary for the development of progressive diabetic nephropathy in susceptible individuals with insulin-dependent diabetes mellitus [1]. Multiple cellular mechanisms are likely involved in the pathogenesis of progressive glomerulosclerosis in diabetic humans and animal models. Loss of normal renal afferent arteriolar contractility resulting in raised intraglomerular pressure is observed in the streptozotocin (STZ) diabetic rat model of nephropathy $[2,3]$. Glomerular mesangial cells respond to raised hydrostatic pressure by increasing transforming growth factor- $\beta_{1}$ and collagen synthesis [4]. Mes- 
angial cells are contractile and resemble vascular smooth muscle cells with respect to their signalling and cytoskeletal responsiveness to vasopressor hormones [5, 6]. Glomeruli isolated from the hyperglycaemic STZ rat demonstrate little or no contractile response of mesangial cells to potent vasoconstrictor peptides including angiotensin II and endothelin-1 (ET-1) [7-9]. Furthermore, no contraction is elicited from STZ rat glomeruli during exposure to the calcium ionophore A23187, confirming the lack of mesangial cell cytoskeletal responsiveness to raised mesangial cell cytosolic calcium [8]. As extracellular glucose concentration increases between 5.6 and $18 \mathrm{mmol} / \mathrm{l}$, cultured rat mesangial cells display progressively reduced contractility to ET-1, despite preservation of normal calcium signalling $[8,9]$.

Recently, we have reported that mesangial cells cultured in high glucose, and the cells of glomeruli isolated from the STZ rat, demonstrate disassembly of filamentous (F-) actin which appears to be protein kinase $\mathrm{C}(\mathrm{PKC})$-dependent $[10,11]$. It is likely that partial disassembly of F-actin accounts for the smaller size of mesangial cells cultured in high glucose compared to those in normal glucose $[10,11]$. Mesangial cells cultured in normal glucose display partial Factin disassembly in response to a vasopressor stimulus [12], creating a favourable arrangement for myosin light chain cross-bridging [13]. The normal contractile response involves both F-actin and myosin light chain phosphorylation stimulated by signalling events including a calcium transient and cytoskeletal protein-specific kinase activation [14]. Vasopressor peptide activation of kinase cascades, including those mediated by PKC, also play a role in cytoskeletal protein phosphorylation. Myosin light chain and caldesmon are phosphorylated by phorbol ester activation of PKC $[15,16]$. Therefore, altered mesangial and renal arteriolar smooth muscle cell contractile function in high glucose may involve PKC-mediated cytoskeletal dysfunction.

Enhanced PKC signalling in high glucose is implicated in the complications of diabetes $[17,18]$, including nephropathy $[19,20]$. One mechanism linking increased intracellular glucose to altered PKC activity is through the polyol pathway. Raised intracellular glucose is converted to sorbitol by aldose reductase. The subsequent synthesis of fructose from sorbitol generates increased NADH which is then available for the conversion of the glycolytic intermediate glycerol-3-phosphate into dihydroxyacetone phosphate, leading to de novo synthesis of diacylglycerol (DAG) $[21,22]$. Membrane accumulation of DAG in high glucose is reported in many cell types including cultured mesangial cells [23] and the cells of isolated STZ diabetic rat glomeruli [24]. DAG in turn, may activate several PKC isoforms. Controversy exists about the time course of increased PKC activity demonstrated by mesangial cells cultured in high glu- cose. Ayo et al. [23], reported increased PKC activity as early as $30 \mathrm{~min}$, and reduced activity at $24 \mathrm{~h}$. Williams and Schrier [25] report a small, but significant increase in mesangial cell PKC activity at both 3 and $24 \mathrm{~h}$ during exposure to high glucose which also correlates with an increase in PKC-dependent phospholipase (PL-) $\mathrm{A}_{2}$ activity and arachidonic acid (AA) release.

The purpose of the present study was to identify a cause and effect relationship between loss of mesangial contractile responsiveness to ET-1 and high glucose metabolism through the polyol pathway contributing to accumulation of DAG and altered PKC activity. Since mesangial cells synthesize a number of PKC isoforms [26], it was further postulated that high glucose concentrations may alter the synthesis and activity of DAG sensitive PKC isoforms which are expressed by mesangial cells and recently reported to accumulate in both vascular smooth muscle [27] and mesangial cells [28]. Metabolism of intracellular glucose through the polyol pathway was monitored by measuring accumulation of sorbitol. The aldose reductase inhibitor ARI-509 (Wyeth-Ayerst, Princeton, N.J., USA) was utilized to prevent the conversion of glucose to sorbitol. In growth-arrested rat mesangial cells after $24 \mathrm{~h}$ exposure to normal glucose $(5.6 \mathrm{mmol} / \mathrm{l})$, high glucose $(30 \mathrm{mmol} / \mathrm{l})$, or high glucose plus ARI-509, the contractile responsiveness to ET-1, membrane-associated DAG accumulation, in situ PKC activity, AA release as a measure of (PL)- $\mathrm{A}_{2}$ activity and PKC-alpha(- $\left.\alpha\right)$, -delta(- $\delta$ ) and epsilon $(-\varepsilon)$ contents were compared.

\section{Materials and methods}

Mesangial cell culture. The chemicals were purchased from ICN, Pharmaceuticals (Montreal, PQ, Canada) or otherwise stated. Glomeruli were isolated under sterile conditions by selective sieving of finely chopped renal cortex from male Sprague-Dawley rats weighing $200 \mathrm{~g}$. Mesangial cells were cultured from isolated glomeruli in minimal essential medium (MEM) with D-valine (Gibco BRL, Mississauga, ON, Canada) at $37^{\circ} \mathrm{C}$ containing $20 \%$ fetal bovine serum (FBS), $5 \mathrm{U} / \mathrm{ml}$ insulin, $100 \mathrm{U} / \mathrm{ml}$ penicillin, and $100 \mu \mathrm{g} / \mathrm{ml}$ streptomycin (Gibco BRL). Cells were harvested by washing two times in phosphate buffered saline (PBS) without calcium and magnesium and briefly exposed to $0.16 \%$ trypsin (Gibco BRL). The effect of trypsin was terminated by adding excess Dulbecco's modified Eagle medium (DMEM) (Gibco BRL) followed by replating. Mesangial cells were identified by their positive immunofluorescence staining for desmin and vimentin, negative staining for cytokeratin and Factor VIII and their positive contractile response to vasopressin [9]. In the following experiments, mesangial cells at passage 10 to 20 were utilized.

Measurement of intracellular glucose, and sorbitol. Intracellular glucose and sorbitol levels were measured as their aldonitril and alditol acetate derivatives by capillary gas liquid chromatography. Mesangial cells were cultured to confluence in DMEM (FBS $20 \%$ ), in either normal or high glucose, with or 
without the aldose reductase inhibitor ARI-509 $(100 \mu \mathrm{mol} / \mathrm{l})$ on $100 \mathrm{~mm}$ culture dishes. The cells were then washed with PBS, harvested by scraping, suspended in $1.0 \mathrm{ml}$ of distilled water and homogenized at $4^{\circ} \mathrm{C}$. Aliquots of the homogenate were treated with an equal volume of $0.3 \mathrm{~N} \mathrm{ZnSO}_{4}$ to precipitate the protein. The solution was neutralized with $\mathrm{Ba}(\mathrm{OH})_{2}$ and centrifuged at $1000 \times g$ for $10 \mathrm{~min}$ at $4{ }^{\circ} \mathrm{C}$. The samples were then lyophilized, extracted with ether, derivatized with hydroxylamine hydrochloride, 4-(dimethylamino)pyridine and acetic anhydride, and injected into an HP-5890 A chromatograph equipped with a SP-2100 fused silica capillary column. Sorbitol was quantitated by flame-ionization detection. Carbohydrate measurements were calculated on the basis of an 8-point standard curve constructed by addition of varying amounts of glucose and sorbitol to homogenates of mesangial cells cultured in normal glucose containing media. The processing and analysis of these samples were identical to those used for the unknown samples. Alpha-methyl mannoside was used as an internal standard. With this technique, the instrument response was linear for concentrations ranging from 6 to $230 \mathrm{nmol}$ per sample. Measurements are expressed as nmol per mg cell protein.

Mesangial cell planar surface area. Rat mesangial cells were cultured for 4 days in DMEM (20\% FBS), with or without the aldose reductase inhibitor, ARI-509 (100 $\mu \mathrm{mol} / \mathrm{l})$, and then transferred to $35 \mathrm{~mm}$ dishes. The cells were cultured for $24 \mathrm{~h}$ in $2 \mathrm{ml}$ DMEM (plus $0.5 \%$ FBS) with either normal $(5.6 \mathrm{mmol} / \mathrm{l})$ glucose, high $(30 \mathrm{mmol} / \mathrm{l})$ glucose, normal glucose $(5.6 \mathrm{mmol} / \mathrm{l})$ plus mannitol $(25 \mathrm{mmol} / \mathrm{l})$, normal glucose plus 50 pmol/l phorbol 12-myristate 13-acetate (PMA) (Sigma Diagnostic, St. Louis, Mo., USA) or high glucose plus $100 \mu \mathrm{mol} / 1$ ARI-509. Then, the dishes were mounted on a heated stage of an inverted light microscope (Bausch and Lomb, New York, N. Y., USA) and change in mesangial cell planar surface area in response to $0.1 \mu \mathrm{mol} / 1 \mathrm{ET}-1$ or $50 \mathrm{pmol} / 1 \mathrm{PMA}$, was observed at $30^{\circ} \mathrm{C} \mathrm{pH} 7.4$ and $5 \% \mathrm{CO}_{2}$, as previously described [8]. Using a video camera attached to the microscope, 10-14 cell images per experiment were captured and digitized at $0 \mathrm{~min}$. Then, either ET-1 or PMA were added directly to the medium to create the above concentrations. Images of the same cells were digitized serially at time intervals from 5 to $60 \mathrm{~min}$. The perimeter of the individual cells with clearly defined borders was outlined $(\times 2)$ and planar surface area calculated using a 486SX PC and JAVA software (Jandel Scientific, San Rafael, Calif., USA). The decrease in planar surface area compared to original size was calculated for each cell. The planar surface area, mean $\pm \mathrm{SEM}$, was determined for each time point.

Cellular membrane-associated DAG. Mesangial cells cultured to confluence in DMEM $(20 \%$ FBS $)$ with or without $100 \mu \mathrm{mol} / \mathrm{l}$ ARI-509, were treated for $24 \mathrm{~h}$ with medium containing $0.5 \%$ FBS, and either normal (5.6 mmol/l), high (30 mmol/l) glucose or high glucose plus ARI-509. DAG mass was estimated using a modified procedure described by Preiss et al. [29] based on the total conversion of extracted DAG to $\left[{ }^{32} \mathrm{P}\right]$ phosphatidic acid (PA) in the presence of $\left[\gamma-{ }^{32} \mathrm{P}\right] \mathrm{ATP}$ and the enzyme $s n-1,2-\mathrm{DAG}$ kinase. The cells were washed with PBS harvested by scraping and the cellular lipids were extracted in $3 \mathrm{ml}$ of chloroform:methanol 100\%: PBS (1:1:0.4, vol/ vol). The phases were split by addition of $1 \mathrm{ml}$ of chloroform and $1 \mathrm{ml} \mathrm{NaCl} 1.0 \mathrm{mmol} / \mathrm{l}$. The lower chloroform phase was washed twice with $2 \mathrm{ml} \mathrm{NaCl} 1.0 \mathrm{mmol} / \mathrm{l}$ and evaporated under $\mathrm{N}_{2}$. Each sample was solubilized in $20 \mathrm{ml}$ of $7.5 \%$ octyl- $\beta$-Dglucoside, $5 \mathrm{mmol} / \mathrm{l}$ cardiolipin, in $1 \mathrm{mmol} / \mathrm{l}$ DETAPAC (Amersham Life Science, Oakville, ON, Canada) and then sonicated for $2 \mathrm{~min}$. The solubilized lipids were mixed with $70 \mu \mathrm{l}$ of a reaction solution containing (mmol/l) 78.5 imidazole- $\mathrm{HCl}$ buffer (pH 6.6), $71.4 \mathrm{NaCl}, 17.8 \mathrm{MgCl}_{2}, 1.4$ EGTA, 0.8 DETAPAC, 2.9 dithiothreitol, 0.7 potassium phosphate, $1.4 \%$ glycer$\mathrm{ol}$ (vol/vol), 0.1 mercaptomethanol, and $0.015 \mathrm{U}$ sn-1,2-DAG kinase (Amersham Life Science). Samples were preincubated in the reaction solution for $5 \mathrm{~min}$ at $25^{\circ} \mathrm{C}$. The reaction was initiated by addition of $10 \mu \mathrm{l}$ of $5 \mathrm{mmol} / 1\left[\gamma^{3}{ }^{32} \mathrm{P}\right] \mathrm{ATP}$, (specific activity $100,000 \mathrm{cpm} / \mathrm{nmol}$, Amersham Life Science). After $30 \mathrm{~min}$, the reaction was stopped by adding $20 \mu \mathrm{l}$ of $1 \%$ perchloric acid (vol/vol) (Sigma Diagnostic) and $450 \mu \mathrm{l}$ of chloroform:methanol $(1: 2 \mathrm{vol} / \mathrm{vol})$. After incubation for $10 \mathrm{~min}$ at room temperature and centrifugation at $2000 \mathrm{~g}$ for $1 \mathrm{~min}$, $150 \mu \mathrm{l}$ of chloroform and $150 \mu \mathrm{l} 1 \%$ perchloric acid, were added to extract the lipids. The lower chloroform phase was washed with $1 \mathrm{ml}$ of $1 \%$ perchloric acid. After the second washing, the chloroform phase was applied to Amprep Si columns $100 \mathrm{mg}$, (Amersham Life Science), preconditioned with $2 \mathrm{ml}$ of hexane (Anachemia Science, Mississauga, ON, Canada). The columns were washed with $2 \mathrm{ml}$ of chloroform followed by $2 \mathrm{ml}$ of ethyl acetate $15 \%$, in hexane (vol/vol). PA was eluted from the columns with $2 \mathrm{ml}$ of solvent system consisting of chloroform: methanol: acetic acid (65:10:10 vol/vol). The radioactivity attributable to $\left[{ }^{32} \mathrm{P}\right] \mathrm{PA}$ was counted. The $s n-$ $1,2-\mathrm{DAG}$ content was calculated from the amount of $\left[{ }^{32} \mathrm{P}\right] \mathrm{PA}$ recovered and specific activity of the $\left[\gamma_{-}{ }^{32} \mathrm{P}\right] \mathrm{ATP}$. A standard curve for the conversion of 1,2-dioleolyl-sn-glycerol 10 to 1000 pmol (Amersham Life Science) to [ $\left.{ }^{32} \mathrm{P}\right] \mathrm{PA}$, was established and found to be linear in this range. The protein concentration of the chloroform phase was measured in a separate sample by the Lowry method using BSA (Bio-Rad, Hercules, Calif., USA) as the standard.

Measurement of PKC activity. Total PKC activity was measured by in situ phosphorylation of the PKC-specific substrate derived from the epidermal growth factor (EGF) receptor (VRKRTLRRL). This substrate was synthesized, in accordance with the published amino acid sequence [30], with an automated solid phase peptide synthesizer and its purity was estimated to be $99 \%$ by HPLC. This method was originally developed by Heasley and Johnson [30] and used to study cultured mesangial cell PKC activity by Williams and Schrier [25].

Mesangial cells were plated onto 96-well flat-bottom microtitre plates at densities of 20,000 cells per well. The cells were cultured for 3-4 days until confluent in DMEM supplemented with $20 \%$ FBS, $5.6 \mathrm{mmol} / \mathrm{l}$ glucose, and with or without $100 \mu \mathrm{mol} / \mathrm{l}$ ARI-509. The monolayers were then incubated for $24 \mathrm{~h}$ in DMEM supplemented with $0.5 \%$ FBS, normal $(5.6 \mathrm{~mol} / \mathrm{l})$ or high $(30 \mathrm{mmol} / \mathrm{l})$ glucose. After incubation, the medium was aspirated and replaced with fresh medium supplemented with or without $50 \mathrm{pmol} / 1 \mathrm{PMA}$, the inactive phorbol 12,13-didecanoate (PDD) $0.1 \mu \mathrm{mol} / 1$ (Calbiochem, San Diego, Calif., USA), the cAMP-dependent kinase inhibitor HA1004 $20 \mu \mathrm{mol} / \mathrm{l}$ (Calbiochem) or the PKC inhibitor calphostin C $0.2 \mu \mathrm{mol} / \mathrm{l}$ (Calbiochem) for 20-30 min. The medium was aspirated and replaced with $40 \mu \mathrm{l}$ of the buffered reaction solution containing $50 \mu \mathrm{g} / \mathrm{ml}$ digitonin, $(\mathrm{mmol} / \mathrm{l}) 137 \mathrm{NaCl}, 5.4 \mathrm{KCl}, 10$ $\mathrm{MgCl}_{2}, 0.3$ sodium phosphate, 0.4 potassium phosphate, $25 \beta$ glycerophosphate, 5.6 or 30 glucose, 5 EGTA, 1 EDTA, $100 \mu \mathrm{mol} / 1$ ATP, $\left[\gamma_{-}{ }^{32} \mathrm{P}\right]$ ATP (specific activity $860 \mathrm{cpm} / \mathrm{pmol}$, Amersham Life Science), 20 Hepes, and the PKC-specific peptide substrate $100 \mu \mathrm{mol} /,\left(\mathrm{pH} 7.2,37^{\circ} \mathrm{C}\right)$. After $10 \mathrm{~min}$ incubation at $30^{\circ} \mathrm{C}$, the reaction was terminated by the addition of $10 \mu \mathrm{l}$ ice cold trichloroacetic acid $25 \%$ (wt/vol), (Caledon). Aliquots $(45 \mu \mathrm{l})$ of the acidified reaction mixtures were spotted onto $2 \mathrm{~cm}$ phosphocelluose paper circles (P81, Gibco BRL) and washed batchwise in three changes $(500 \mathrm{ml}$ each) of $1 \%$ 
phosphoric acid, $0.1 \%$ Tween 20 and one change of $75 \mathrm{mmol} / \mathrm{l}$ sodium phosphate, $(\mathrm{pH} 7.5)$. Due to the basicity of the PKC substrate peptide, it is retained on the phosphocellulose paper at neutral $\mathrm{pH}$ while the excess $\left[\gamma_{-}{ }^{32} \mathrm{P}\right]$ ATP bound to the filters at acidic $\mathrm{pH}$ is removed [30]. To determine background phosphorylation, the assay was performed in the absence of VRKRTLRRL.

$A A$. Rat mesangial cells were grown to confluence in DMEM (20\% FBS). Two days prior to the experiment, cells were split into $60 \mathrm{~mm}$ diameter dishes DMEM (20\% FBS). Confluent monolayers were preincubated for $24 \mathrm{~h}$ with $0.2 \mu \mathrm{Ci}$ of ${ }^{3} \mathrm{H}$ arachidonic acid $\left({ }^{3} \mathrm{H}\right.$-AA) (Amersham Life Science) in $1 \mathrm{ml}$ DMEM, $0.5 \%$ FBS. Radioactive medium was aspirated $24 \mathrm{~h}$ later and cells were washed gently $(\times 5)$ with $2 \mathrm{ml}$ of washing medium which consisted of DMEM (glucose $5.6 \mathrm{mmol} / \mathrm{l}$ ), $0.5 \% \mathrm{FBS}$ and $5 \mathrm{mg} / \mathrm{ml}$ BSA. After washing, cells were incubated for 3 or $24 \mathrm{~h}$ at $37^{\circ} \mathrm{C}$ in $2 \mathrm{ml}$ of incubation medium which consisted of DMEM, $0.5 \% \mathrm{FBS}, 1 \mathrm{mg} / \mathrm{ml} \mathrm{BSA}$ and either normal or high glucose. After incubation, the medium was aspirated and cells were washed five times with washing medium as above and $1 \mathrm{ml}$ of corresponding incubation medium was added for an additional $30 \mathrm{~min}$ incubation at $37^{\circ} \mathrm{C}$. A $750 \mu \mathrm{l} \mathrm{sam}-$ ple of medium was removed without touching the cells. The sample was centrifuged at $8000 \mathrm{rev} / \mathrm{min}$ for $10 \mathrm{~min}$, and used for scintillation counting. Results were multiplied by $4 / 3$ to determine the amount of ${ }^{3} \mathrm{H}$-AA released by the monolayer into $1 \mathrm{ml}$ incubation medium over a $30 \mathrm{~min}$ period.

To compare EGF-stimulated ${ }^{3} \mathrm{H}$-AA response, radiolabelled monolayers were washed with washing medium, as above, then the cells were exposed to $1 \mathrm{ml}$ of incubation medium with normal $(5.6 \mathrm{mmol} / \mathrm{l})$ glucose supplemented with 100 $\mathrm{nmol} / \mathrm{l} \mathrm{EGF}$ (Sigma Diagnostic) for $20 \mathrm{~min}$ plus calcium ionophore A23187 (Calbiochem) $2 \mu \mathrm{mol} / 1$ for $5 \mathrm{~min}$ as a positive control, or the acetic acid vehicle $(100 \mathrm{nmol} / \mathrm{l})$ for $25 \mathrm{~min}$ as a negative control, $37^{\circ} \mathrm{C}$. The dimethyl sulfoxide (DMSO) vehicle was added for $5 \mathrm{~min}$ at a final concentration $0.5 \%$, to the negative control.

After removal of radioactive medium, cells were washed five times with PBS and lysed with $1 \mathrm{ml}$ per well of $0.1 \mathrm{~mol} / \mathrm{l}$ $\mathrm{NaOH}$ for $1 \mathrm{~h}$. The wells were scraped and the entire lysate was collected, vortexed, and $50 \mu \mathrm{l}$ aliquots were removed for scintillation counting. The results were standardized by expressing the total amount of ${ }^{3} \mathrm{H}$-AA released as a percentage of total ${ }^{3} \mathrm{H}-\mathrm{AA}$ initially incorporated by the cells.

Immunoblot analysis of PKC isoforms. Rat mesangial cells were cultured to confluence in $60 \mathrm{~mm}$ diameter dishes and then exposed for $24 \mathrm{~h}$ to normal $(5.6 \mathrm{mmol} / \mathrm{l})$ or high $(30 \mathrm{mmol} / \mathrm{l})$ glucose in $0.5 \% \mathrm{FBS}$, with or without $100 \mu \mathrm{mol} / 1$ ARI-509. The cells were washed with PBS $(\times 2)$, scraped in $300 \mu \mathrm{l}$ lysis buffer, (mmol/l) $1 \mathrm{NaHCO}_{3}, 5 \mathrm{MgCl}_{2} \cdot 6 \mathrm{H}_{2} \mathrm{O}, 50$ Tris- $\mathrm{HCl}, 10$ EGTA, 2 EDTA, $25 \mu \mathrm{g} / \mathrm{ml}$ leupeptin, $1 \% 2-\beta$ mercaptoethanol, 0.6 phenylmethylsulfonyl fluoride, $1 \%$ Triton-X-100, and $1 \%$ sodium dodecyl sulfate. DNA was removed with a DNA filter (SQ-Easy Filters, Porex Technologies, Fairburn, Ga., USA). The protein concentration was determined by the Bradford method (Bio-Rad Laboratories, Mississauga, ON, Canada) and $50 \mu \mathrm{g}$ of total cell protein/lane along with molecular weight markers were loaded onto an Immobilon PVDF membrane (Millipore, Bedford, Mass., USA) for $2 \mathrm{~h}$ at $250 \mathrm{~mA}$ using a Bio-Rad Transblot apparatus. The membrane was blocked for $2 \mathrm{~h}$ in blocking buffer $(5 \%$ nonfat dry milk powder, $5 \% \mathrm{BSA}, 10 \mathrm{mmol} / \mathrm{l}$ Tris $\mathrm{HCl}, 150 \mathrm{mmol} / \mathrm{l}$ $\mathrm{NaCl}$, and $0.05 \%$ Tween-20, [vol/vol]), at room temperature. Then the membrane was incubated first with monoclonal PKC- $\alpha,-\delta$, or $-\varepsilon$ antisera $0.5 \mu \mathrm{g} / \mathrm{ml}$ (Bio/Can Scientific, Missis- sauga, ON, Canada) in incubation buffer without BSA, and second with horseradish peroxidase-conjugated goat antimouse IgG, diluted 1:5000 (Bio/Can Scientific). The membranes were thoroughly washed after each incubation with $10 \mathrm{mmol} / \mathrm{l}$ Tris- $\mathrm{HCl}, 150 \mathrm{mmol} / 1 \mathrm{NaCl}$, and $0.05 \%$ Tween-20 and the final wash was in the absence of detergent. A chemiluminescence kit (Canadian life Technologies, Burlington, ON, Canada) and Kodak X-Omat AR film (Eastman Kodak, Rochester, N. Y., USA) were used for development. The PKC-isoforms were identified using molecular weight markers and positive controls (Bio/Can Scientific). To determine the density of the single bands, these images were digitized using the White/ UV transilluminator, Gel Documentation System and UV Image Store 5000 (UVPm Diamed Lab Supplies, Mississauga, ON, Canada). Then the area of each specific band was calculated using JAVA software and multiplied by its mean pixel intensity (grey scale 1 to 255) to obtain total density. Background intensity was subtracted from each band.

Statistical analyses were performed using analysis of variance (ANOVA) with Bonferroni correction for multiple comparisons. All data are presented as mean values \pm SEM.

\section{Results}

Effects of high glucose and ARI-509 on mesangial intracellular glucose and sorbitol levels. The intracellular glucose level ( $n=7$ per group) increased from $1095 \pm 208 \mathrm{nmol} / \mathrm{mg}$ cell protein in normal glucose to $7215 \pm 491 \mathrm{nmol} / \mathrm{mg}$ cell protein in high glucose $(p<0.01$ vs normal glucose) which was unchanged in high glucose plus ARI-509, $6816 \pm 203 \mathrm{nmol} / \mathrm{mg}$ cell protein. The sorbitol level in normal glucose was $5.1 \pm 0.9 \mathrm{nmol} / \mathrm{mg}$ cellular protein and increased in high glucose to $17.0 \pm 1.3 \mathrm{nmol} / \mathrm{mg}$ cellular protein, $(p<0.01$ vs normal glucose). The sorbitol content in both normal and high glucose was significantly reduced by $100 \mu \mathrm{mol} / \mathrm{l}$ ARI-509, to $3.7 \pm 0.5(p<0.01$ vs normal glucose without ARI-509) and 7.1 \pm 1.1 $\mathrm{nmol} / \mathrm{mg}$ cell protein $(p<0.01$ vs high glucose without ARI-509), respectively, indicating that mesangial cell aldose reductase was inhibited.

Effect of high glucose, ARI-509 and phorbol ester on mesangial cell contraction. Figure 1 demonstrates the change in planar surface area of mesangial cells incubated for $24 \mathrm{~h}$ in normal glucose stimulated with $0.1 \mu \mathrm{mol} / 1 \mathrm{ET}-1$. The planar surface area of mesangial cells in normal glucose prior to stimulation with ET-1 at zero time was $3109 \pm 131 \mu \mathrm{m}^{2},(n=31$ cells $)$. During ET-1 exposure, surface area decreased over $60 \mathrm{~min}$ to $52 \pm 3 \%$ of the original surface area $(p<0.05$ vs no agonist). Cells $(n=20)$ incubated in normal glucose plus mannitol demonstrated similar planar area, $3274 \pm 132 \mu \mathrm{m}^{2}$ compared to cells in normal glucose and contracted in response to ET-1 to $72 \pm 5 \%$ of original volume over $60 \mathrm{~min}$. The cells incubated in high glucose demonstrated a smaller initial planar surface area of $2547 \pm 148 \mu \mathrm{m}^{2}, \quad(n=41$ cells, $p<0.05$ vs normal glucose) and did not respond 


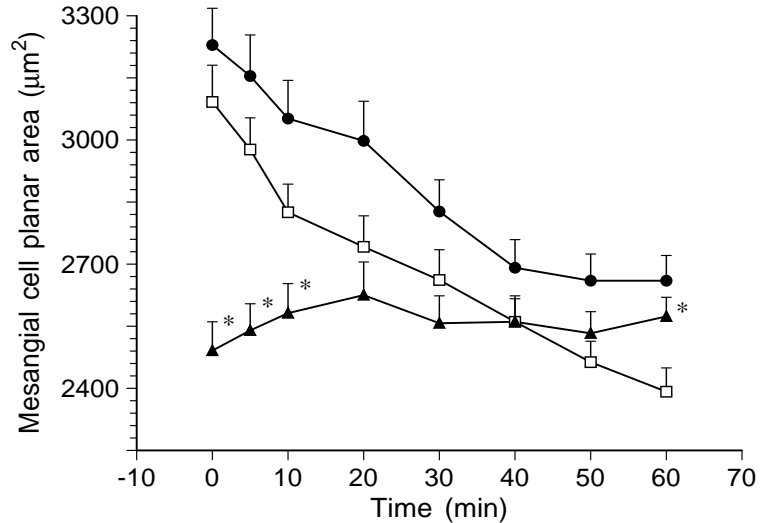

Fig.1. Effect of high glucose (HG) and ARI-509 (ARI) on endothelin-1-stimulated mesangial cell contraction and change in planar surface area. Mesangial cells were cultured 4 days in either normal glucose (NG) $5.6 \mathrm{mmol} / \mathrm{l}(\square), \mathrm{HG} 30 \mathrm{mmol} / \mathrm{l}$ (A) or HG + ARI $100 \mu \mathrm{mol} / \mathrm{l}(\mathbf{O})$, in DMEM supplemented with $20 \%$ FBS, then transferred to $20 \mathrm{~mm}$ dishes and rendered quiescent for $24 \mathrm{~h}$ in DMEM, $0.5 \%$ FBS in either NG $(n=31$ cells), HG $30 \mathrm{mmol} / \mathrm{l}(n=24)$, or $\mathrm{HG}+\mathrm{ARI}(n=42$ cells $)$. At time $0 \mathrm{~min}, 0.1 \mu \mathrm{mol} / \mathrm{l}$ endothelin- 1 was added to the medium and cell planar surface area was measured serially. Data pooled from three separate experiments are presented as the mean \pm SEM for each time point. ${ }^{*} p<0.05$ vs NG

to ET-1 stimulation, see Figure 1. The initial planar surface area of the cells incubated in high glucose plus ARI-509 was $3274 \pm 132 \mu \mathrm{m}^{2}, \quad(n=42$ cells $)$. Treatment with ARI-509 normalized the contractile response to ET-1 of the cells cultured in high glucose which demonstrated a decrease in surface area to $70 \pm 4 \%$ of original ( $n=42$ cells, $p<0.05$ vs no agonist).

Figure 2 indicates that mesangial cells cultured for $24 \mathrm{~h}$ in normal glucose, when stimulated acutely with $50 \mathrm{pmol} / 1 \mathrm{PMA}$, demonstrated decreased surface area to $66 \pm 3 \%$ of original ( $p<0.05$ vs no agonist, $n=15$ cells) over $60 \mathrm{~min}$.

To determine whether ET-1 stimulation of contraction requires PKC, mesangial cells $(n=30)$ were cultured for $24 \mathrm{~h}$ in normal glucose, supplemented with $50 \mathrm{pmol} / \mathrm{l}$ PMA. Figure 3 demonstrates that when PKC was downregulated, no contractile response to ET-1 was observed. Also, the planar surface area in normal glucose supplemented with $50 \mathrm{pmol} / 1$ PMA for $24 \mathrm{~h}$ was $2513 \pm 125 \mu \mathrm{m}^{2}(n=34)$ resembling the cells cultured in high glucose.

Cell membrane DAG accumulation. The membraneassociated DAG content of cells incubated in normal glucose for $24 \mathrm{~h}$ was $688 \pm 113 \mathrm{pmol} / \mathrm{mg}$ protein DAG $(n=11)$. No significant change in DAG content was observed at $3 \mathrm{~h}$ of high glucose exposure. After $24 \mathrm{~h}$ in high glucose, the DAG content was elevated to $1110 \pm 49 \mathrm{pmol} / \mathrm{mg}$ protein, $(n=16, p<0.05 \mathrm{high}$ vs normal glucose). Treatment with ARI-509 prevented

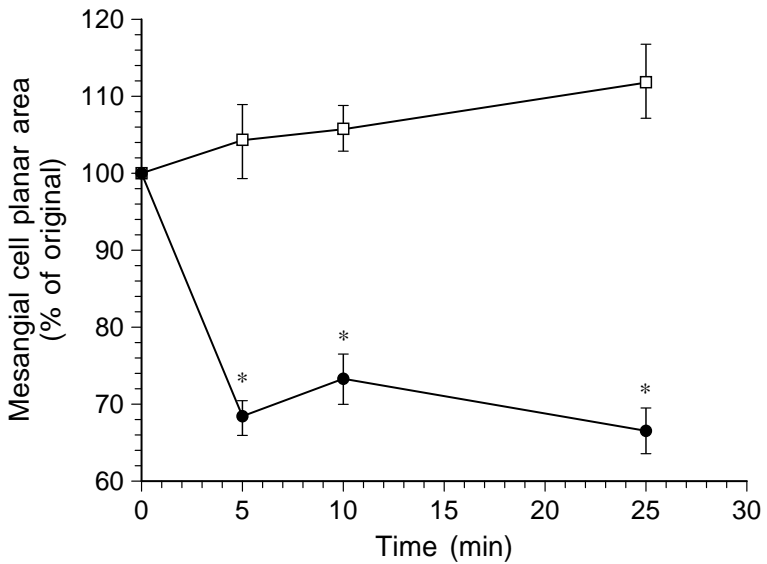

Fig. 2. Phorbol 12-myristate 13-acetate (PMA)-stimulated contraction of mesangial cells. Mesangial cells were cultured 4 days in normal glucose (NG) $5.6 \mathrm{mmol} / 1$, in DMEM supplemented with $20 \%$ FBS, then transferred to $20 \mathrm{~mm}$ dishes for $24 \mathrm{~h}$. Cell planar area was analysed at the time intervals indicated following addition of $50 \mathrm{pmol} / \mathrm{l}$ PMA $(\mathbf{O})(n=15$ cells $)$ or its vehicle DMSO $(\square)$ at final concentration $0.25 \%$ (vol/ vol) $(n=20$ cells $)$. The percent of original surface area $(100 \%)$ was calculated for each cell. Data pooled from two separate experiments are expressed as mean \pm SEM for each time point. ${ }^{*} p<0.05$ vs NG + DMSO

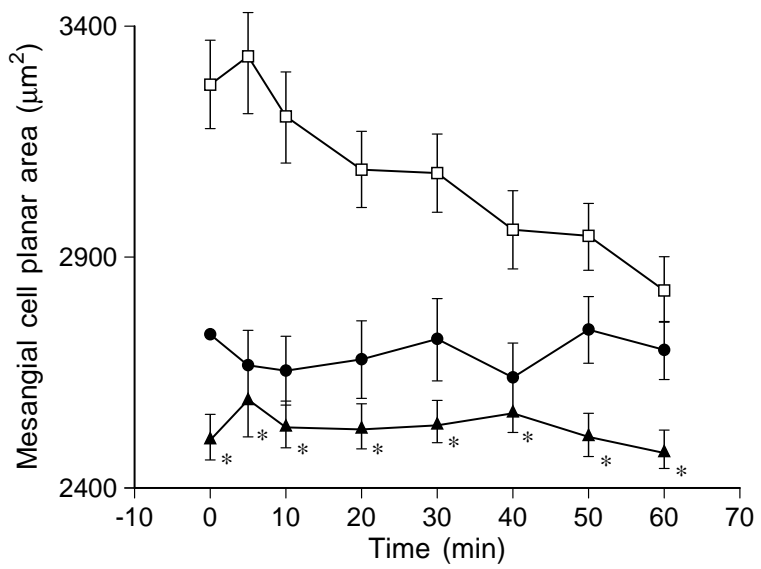

Fig. 3. Endothelin-1-stimulated contraction and planar area of mesangial cells, effect of phorbol 12-myristate 13-acetate (PMA) exposure for $24 \mathrm{~h}$. Mesangial cells were cultured 4 days in normal glucose (NG) $5.6 \mathrm{mmol} / \mathrm{l}$, in DMEM supplemented with $20 \%$ FBS, then transferred to $20 \mathrm{~mm}$ dishes for $24 \mathrm{~h}$ in either $\mathrm{NG}(\square)(n=30$ cells $)$, high glucose (HG) $30 \mathrm{mmol} / \mathrm{l}(\boldsymbol{O})(n=20$ cells $)$, or $\mathrm{NG}+\mathrm{PMA} 50 \mathrm{pmol} / \mathrm{l}(\boldsymbol{\Delta})$ $(n=34$ cells $)$. At time $0 \mathrm{~min} 0.1 \mu \mathrm{mol} / 1$ endothelin- 1 was added to the medium and the cell planar area was analysed serially. Data pooled from three separate experiments are presented as the mean \pm SEM for each time point. ${ }^{*} p<0.05$ vs NG

high glucose-mediated increase in DAG measured at $776 \pm 168 \mathrm{pmol} / \mathrm{mg}$ protein $(n=6)$.

Effect of high glucose, and phorbol ester on PKC activity. As illustrated in Figure 4A, in normal glucose incubation for $15 \mathrm{~min}$ with $50 \mathrm{pmol} / \mathrm{l} \mathrm{PMA}$ increased 

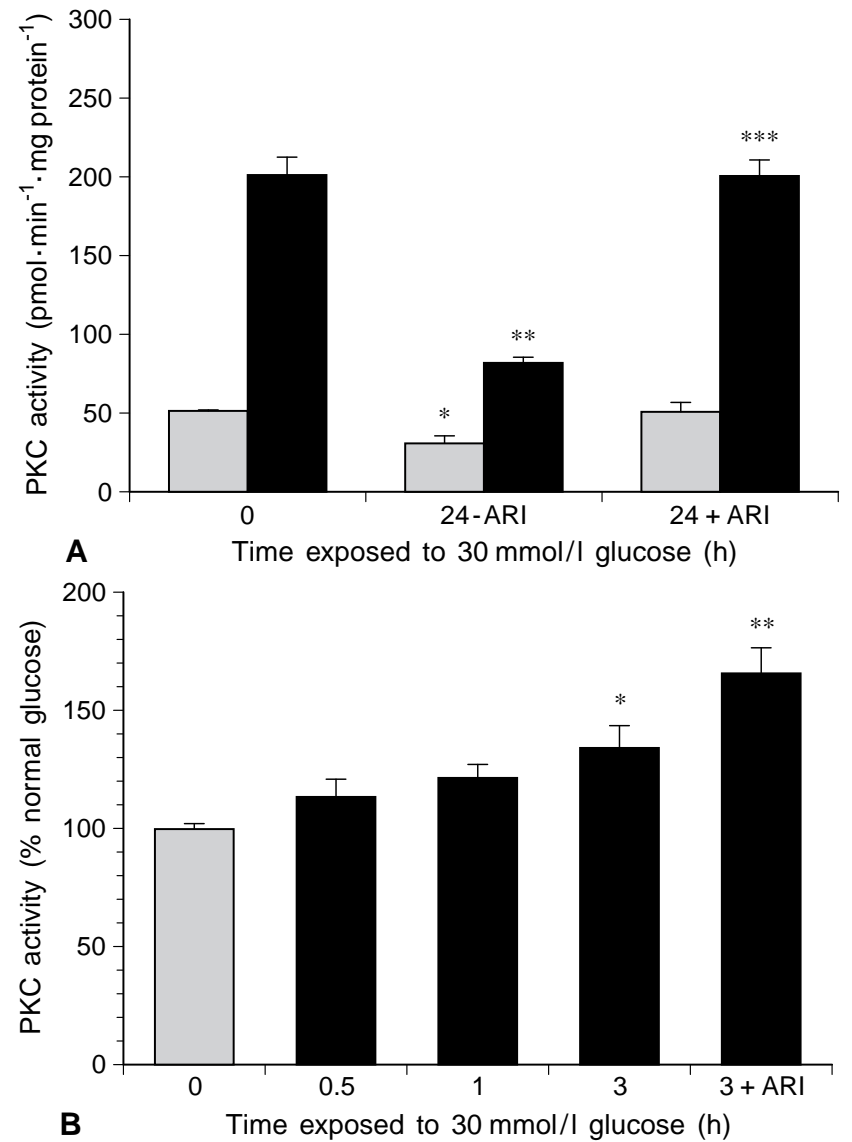

Fig. 4 A, B. Effect of high glucose (HG) on mesangial cell protein kinase $\mathrm{C}(\mathrm{PKC})$ activity. Confluent mesangial cells were incubated for $24 \mathrm{~h}$ in DMEM $(0.5 \%$ FBS $)$ in either normal glucose (NG) $5.6 \mathrm{mmol} / \mathrm{l}(n=40)$, HG $30 \mathrm{mmol} / 1 \quad(n=40)$, or $\mathrm{HG}+\mathrm{ARI} 100 \mu \mathrm{mol} / \mathrm{l}(n=40)$. Following this incubation and additional incubation with $50 \mathrm{pmol} / \mathrm{l}$ phorbol 12-myristate 13acetate (PMA) for $10 \mathrm{~min}$ ( $n=20$ from each group), PKC activity was measured in situ in digitonin-permeabilized cells by detecting the phosphorylation $\left(\mathrm{pmol} \cdot \mathrm{min}^{-1} \cdot \mathrm{mg}\right.$ total cell protein $^{-1}$ ) of a PKC-specific peptide substrate (VRKTLRRL). A At $24 \mathrm{~h}$ of high glucose, basal $\square$ and PMA-stimulated PKC activities were significantly reduced and normalized with ARI-509. B High glucose exposure at $3 \mathrm{~h}$ caused an increase of basal $\square$, but not PMA-stimulated $\square$ PKC activity (not shown) compared to normal glucose $(0 \mathrm{~min})$. ARI-509 did not alter increased PKC-activity at $3 \mathrm{~h}$. Data are expressed as mean \pm SEM. $* p<0.05$ vs basal $0 \mathrm{~h}, * * p<0.05$ vs PMAstimulated at $0 \mathrm{~h}, * * * p<0.05 \mathrm{vs}$ PMA-stimulated at $24 \mathrm{~h}$

phosphorylation of the PKC-specific EGF-receptor substrate from $50 \pm 3$ (basal) to $200 \pm 15$ $\mathrm{pmol} \cdot \mathrm{min}^{-1} \cdot \mathrm{mg}$ protein ${ }^{-1}$. Exposure to $0.1 \mu \mathrm{mol} / 1$ PDD, an inactive structural analogue of PMA, did not stimulate PKC activity. Exposure of mesangial cells to $0.2 \mu \mathrm{mol} / 1$ calphostin $\mathrm{C}$, an inhibitor of PKC, for 30 min prevented PMA activation of PKC. Similarly, $24 \mathrm{~h}$ exposure of mesangial cells to PMA reduced basal activity to $20 \pm 7 \mathrm{pmol} \cdot \mathrm{min}^{-1} \cdot \mathrm{mg}$ protein $^{-1}$ which was unchanged when stimulated with ET-1. Preincubation of cells with $20 \mu \mathrm{mol} / \mathrm{l} \mathrm{HA} 1004$, which inhibits cAMP-dependent kinase, for $30 \mathrm{~min}$ did not affect PMA-mediated PKC activation (data not shown). In high glucose at $24 \mathrm{~h}$, basal and PMAstimulated PKC activities decreased significantly $(p<0.05$, vs time 0$)$ and remained normal in the presence of ARI-509 (Fig. 4A).

Figure 4B indicates that high glucose exposure for $3 \mathrm{~h}$ increased basal PKC activity to $132 \pm 7 \%$ above normal glucose $(p<0.05$ vs time 0$)$. No effect of ARI-509 on high glucose-stimulated basal activity was observed.

${ }^{3} \mathrm{H}-\mathrm{A} A$ release. In normal glucose, ${ }^{3} \mathrm{H}-\mathrm{AA}$ release in the presence of $100 \mathrm{nmol} / \mathrm{l} \mathrm{EGF}$ plus A23187, as a positive control, was $13.8 \pm 0.6 \%$ of total cellular ${ }^{3} \mathrm{H}$ AA and was significantly different from ${ }^{3} \mathrm{H}$-AA release in the presence of the vehicle, $1.8 \pm 0.3 \%$ $(n=7, p<0.05)$. When the cells were incubated for $3 \mathrm{~h}$ in either normal or high glucose, the unstimulated, basal release was $2.0 \pm 0.5 \%$ and $1.2 \pm 0.3 \%$ of total ${ }^{3} \mathrm{H}$-AA, respectively, $(n=9$, no significant difference). Cells incubated for $24 \mathrm{~h}$ in either normal or high glucose released $1.9 \pm 0.4 \%$ and $2.1 \pm 0.4 \%$ of total ${ }^{3} \mathrm{H}$-AA, respectively $(n=9$, no significant difference).

Immunoblot mesangial cell PKC-isoforms. Figure 5 illustrates the representative immunoblots of mesangial cell total PKC $-\alpha,-\delta$ and $-\varepsilon$ in normal and high glucose, with or without ARI-509. Protein loading of $50 \mu \mathrm{g} / \mathrm{lane}$, observed by Coomassie blue staining, was identical in all lanes. The densitometry data pooled from 5-6 individual experiments are shown. No significant differences in total PKC- $\alpha$ (Fig. 5A), or PKC- $\delta$ (Fig. 5B) were observed in high glucose after $24 \mathrm{~h}$ or in the presence of ARI-509. No change in total PKC- $\varepsilon$ was observed in high glucose after $24 \mathrm{~h}$ (Fig.5C). ARI-509 significantly reduced the content of PKC- $\varepsilon$ in both normal and high glucose conditions $(p<0.05$ vs no ARI-509). No effect of mannitol on PKC- $\alpha,-\delta$ or $-\varepsilon$ was observed and exposure to PMA for $24 \mathrm{~h}$ reduced mesangial PKC- $\alpha,-\delta$ and $-\varepsilon$ to approximately $50 \%$ of normal recovery on immunoblot (data not shown).

\section{Discussion}

Metabolism of excess glucose through the polyol pathway is implicated in the pathogenesis of diabetic complications [31, 32]. The findings of our study link this mechanism to acute changes in mesangial cell contractile function which may have relevance to the early glomerular hemodynamic changes observed in the STZ rat. It was postulated that in high glucose altered PKC function may contribute to polyol pathway-dependent loss of normal mesangial cell contractile responsiveness. In high glucose, the loss of mesangial cell normal contraction in response to ET-1, 


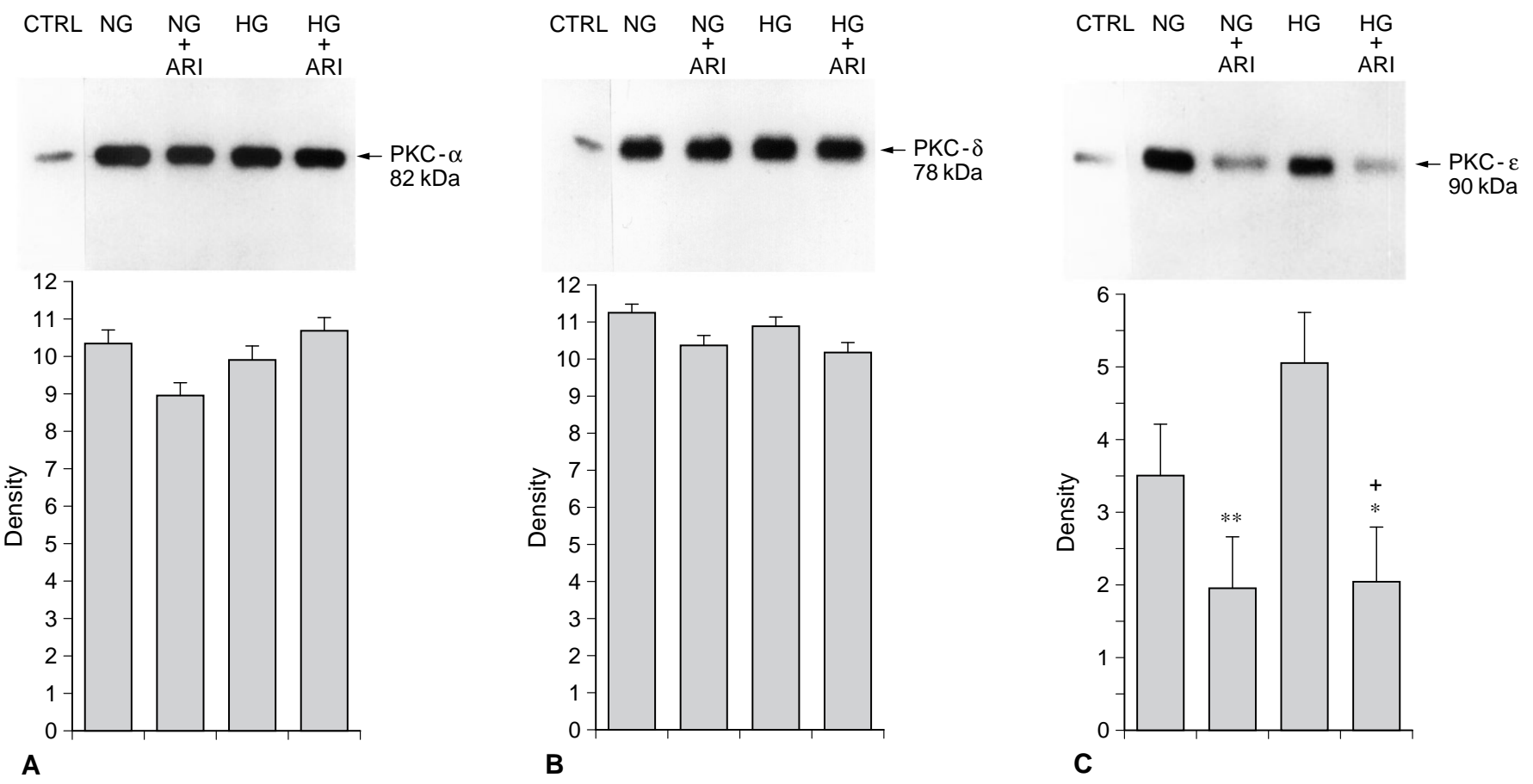

Fig. 5. Effect of high glucose (HG) and aldose reductase inhibition on PKC-isoform accumulation. Mesangial cells were cultured to confluence in normal glucose (NG) $5.6 \mathrm{mmol} / \mathrm{l}$ or HG $30 \mathrm{mmol} / \mathrm{l}$, with or without $100 \mu \mathrm{mol} / \mathrm{l}$ ARI-509, then rendered quiescent for $24 \mathrm{~h}$ in $0.5 \%$ FBS. Total PKC-isoform content was analysed by Western analysis using primary monoclonal antibodies. Representative immunoblots are shown above and positive PKC-isoforms were used to identify the antibody specificity along with the determination of size from the simultaneously electrophoresed molecular markers. A single band of the molecular size indicated was observed in each blot. The histogram represents the mean \pm SEM of band densitometry measured in 5-6 separate experiments. A Total PKC$\alpha$ remained unchanged in high glucose and with ARI-509. B Total PKC- $\delta$ remained unchanged in high glucose and with ARI-509. C Total PKC- $\varepsilon$ remained unchanged in high glucose. In the presence of ARI-509, total PKC- $\varepsilon$ decreased in both normal and high glucose. ${ }^{*} p<0.05 \mathrm{vs} \mathrm{HG}^{* *} p<0.05 \mathrm{vs} \mathrm{NG}$, ${ }^{+}$not significantly different from NG + ARI

decrease in PKC activity and accumulation of DAG at $24 \mathrm{~h}$ are all prevented by aldose reductase inhibition. Early activation of mesangial cell PKC following $3 \mathrm{~h}$ exposure to high glucose appears to be independent of the polyol pathway. No alteration in membrane-associated DAG, at least within the sensitivity of our DAG assay, was observed at $3 \mathrm{~h}$ suggesting no specific cause and effect relationship between increased PKC activity and de novo synthesis of DAG. In normal glucose, downregulation of PKC activity by phorbol ester rendered mesangial cells smaller and unresponsive to ET-1, similar to the high glucose state. However, the immunoblot data revealed no change in total cellular PKC- $\alpha$, $-\delta$, and $-\varepsilon$ following high glucose exposure for $24 \mathrm{~h}$ despite reduced PKC activity. Therefore, either the moderately increased $\mathrm{PKC}$ activity at $3 \mathrm{~h}$ was insufficient to downregulate PKC- $\alpha,-\delta$, and $-\varepsilon$, or expression of these isoforms was simultaneously enhanced in high glucose. ARI509 significantly reduced mesangial cell PKC- $\varepsilon$ in both normal and high glucose, with no significant alteration in PKC- $\alpha$ or $-\delta$ suggesting a selective effect of the polyol pathway on PKC- $\varepsilon$. Since, in high glucose ARI-509 reduces PKC- $\varepsilon$ but restores PKC activity to normal, the EGF-receptor substrate phosphorylation assay may reflect PKC activity excluding PKC- $\varepsilon$. The complex and time-dependent action of high glucose on DAG accumulation and altered PKC activity, as well as the unknown PKC isoform specificity of the PKC-activity assay, may have prevented the identification of a strict cause and effect relationship between high glucose-enhanced DAG synthesis and PKC activity. Nevertheless, the data do support a relationship between the polyol pathway and PKC-dependent altered mesangial cell contractility in high glucose.

The loss of normal glomerular afferent arteriolar tone in diabetes is due to the effect of high glucose on vascular smooth muscle cells. The normalization of STZ rat glomerular arteriolar contractile function in the presence of an aldose reductase inhibitor, has been reported by Bank et al. [33]. More recently polyol-dependent afferent arteriolar dilatation in the galactose-fed hydronephrotic rat has been demonstrated using direct videomicroscopy by Forster et al. [34]. We have also observed that tolrestat-treated hyperglycaemic STZ rats have normal glomerular filtration and renal plasma flow, no increase in microalbuminuria and no glomerular hypertrophy in the first 12 weeks of diabetes [35]. Glomeruli isolated 
from tolrestat-treated STZ rats contract normally in response to ET-1 [35]. These in vivo findings implicate the polyol pathway in the mediation of the high glucose effect on renal microcirculation.

Our study examines the status of mesangial cells exposed to high glucose up to $24 \mathrm{~h}$. The time duration was chosen because we focused on the analysis of contractility in vitro. The mesangial cells take $24 \mathrm{~h}$ to adhere and spread onto the culture dishes, a requirement for the videomicroscopy measurement of change in cell size. DAG and PKC were analysed in relation to this functional outcome.

Mesangial cell contractility in vitro is well characterized. Mesangial cells in culture retain many important phenotypic characteristics found in vivo, including vasopressor peptide receptor expression, signalling cascades and cytoskeletal protein responses. However, cultured mesangial cells assume a flattened, almost two-dimensional form in contrast to their three-dimensional shape and smaller size in vivo. To observe mesangial cell contraction in response to reorganization and shortening of the cytoskeleton in vitro, the mesangial cells must also partially detach from the substratum. In this study, the finding of smaller mesangial cells unresponsive to ET-1 when cultured in high glucose could be due to a number of changes which are not mutually exclusive. These include partial disassembly of F-actin, as we have observed previously [11], other cytoskeletal changes, such as myosin light chain "pre"-phosphorylation (independent of a signalled event), less cellular attachment or decreased activity of DAG-sensitive PKC-isoform(s) which are necessary for a normal contractile response. ARI-509 normalized mesangial cell size and contractile response to ET-1 in high glucose (Fig. 1A,B), indicating a mechanism related to glucose metabolism through the polyol pathway.

The stimulation of mesangial cells with a vasoactive agent, such as ET-1, initiates a series of signalling events including raised intracellular calcium which is unchanged in high glucose in our hands [8]. Calciumcalmodulin stimulates myosin light chain kinase [36] which phosphorylates myosin light chain. The resultant cross-bridging of myosin light chain to F-actin causes cytoskeletal shortening and cell contraction [14]. Another consequence of vasopressor signalling is disassembly of F-actin from a bundled to more of a network pattern [11]. This complex process involves several reactions including calcium-dependent severing of F-actin filaments, and activation of actin-ATPase [14]. Another potential link between polyol-dependent de novo synthesis of signalling molecules is via lysophosphatidic acid (LPA), a precursor of DAG [37]. LPA stimulates fibroblasts through a Gprotein coupled Rho pathway [38]. Rho-dependent inhibition of myosin light chain phosphatase, which indirectly enhances myosin light chain phosphorylation, was reported recently by Kimura et al. [39].
Pre-phosphorylation of myosin light chain, subsequent precontraction and loss of contractile response to ET-1, all prevented by aldose reductase inhibition, could explain the results reported here.

No change in $\left[{ }^{3} \mathrm{H}\right]$-AA release in high glucose at $24 \mathrm{~h}$ was observed. These data imply that high glucose-induced loss of contractility within $24 \mathrm{~h}$ is unlikely to be mediated by AA vasoactive metabolites. The difference between our data and the results of Williams and Schrier [25] who reported a small, but significant increase in $\left[{ }^{3} \mathrm{H}\right]-\mathrm{AA}$ in high glucose, may be explained by differences in experimental conditions. We have studied the effects of high glucose in the growth-arrested state assuming that cell signalling may be modified by the multiple growth factors present in higher concentrations of FBS. As well, the passage of our cells ranged from 10 to 20 , compared to less than 10 reported by Williams and Schrier [24]. Also, clonal selection could influence phenotypic expression of signalling factors. In the STZ diabetic rat, increased glomerular (PL)- $\mathrm{A}_{2}$ activity leads to enhanced synthesis of vasodilatory prostaglandin $\mathrm{E}_{2}$ [40]. Recently, Trachtman et al. [41] reported that mesangial cells cultured in high glucose demonstrate a decline in nitric oxide and cyclic GMP generation, which could potentiate the vasoconstrictor effect of ET-1. Previously [8], our laboratory reported that preincubation of mesangial cells with either indomethacin or $\mathrm{N}^{\mathrm{G}}$-nitro-L-arginine methyl ester had no effect on high glucose-induced loss of contractility, indicating that altered synthesis of autocrine vasodilatory agents are probably not involved in contractile dysfunction.

In summary, this study identifies the importance of the polyol pathway in the mediation of early high glucose effects on mesangial cells. Aldose reductase inhibition prevents high glucose-induced loss of the mesangial cell contractile response to ET-1. Through the polyol pathway, high glucose also causes mesangial cell DAG accumulation, altered PKC activity and reduced PKC- $\varepsilon$ content, one or more of which may contribute to altered mesangial cell contractility. A functional relationship between de novo DAG and increased PKC activity following $3 \mathrm{~h}$ exposure to high glucose was not observed. More detailed examination of the effects of high glucose on mesangial cell DAG-sensitive PKC isoform expression and function are required.

Acknowledgements. This research was funded by the National Kidney Foundation of Canada and by the Medical Research Council of Canda Group in Membrane Biology grant.

\section{References}

1. The Diabetes Control and Complications Trial Research Group (1993) The effect of intensive treatment of diabetes on the development and progression of long-term complications 
B. Derylo et al.: High glucose-induced mesangial cell altered contractility

in insulin-dependent diabetes mellitus. N Engl J Med 329: 977-986

2. Hostetter TH, Troy JL, Brenner BM (1981) Glomerular hemodynamics in experimental diabetes mellitus. Kidney Int 19: 410-415

3. Zatz R, Meyer TW, Rennke HG, Brenner BM (1985) Predominance of hemodynamic rather than metabolic factors in the pathogenesis of diabetic glomerulopathy. Proc Natl Acad Sci USA 82: 5963-5967

4. Riser BL, Cortes P, Zhao X, Bernstein J, Dumier F, Narins RG (1992) Intraglomerular pressure and mesangial stretching stimulates extracellular matrix formation in the rat. J Clin Invest 90: 1932-1943

5. Schlondorff D (1987) The glomerular mesangial cell: an expanding role for a specialized pericyte. FASEB J 1: 272-281

6. Mene P, Simonson MS, Dunn MJ (1989) Physiology of the mesangial cell. Physiol Rev 69: 1347-1424

7. Kikkawa R, Kitamura E, Fujiwara Y, Arimura T, Haneda M, Shigeta Y (1986) Impaired contractile responsiveness of diabetic glomeruli to angiotensin II: a possible indication of mesangial dysfunction in diabetes mellitus. Biochem Biophys Res Commun 136: 1185-1190

8. Hurst RD, Stevanovic ZS, Munk S et al. (1995) Glomerular mesangial cell altered contractility in high glucose is calcium independent. Diabetes 44: 759-766

9. Hurst RD, Whiteside CI, Thompson JC (1992) Diabetic rat glomerular mesangial cells display normal inositol trisphosphate and calcium release. Am J Physiol 263: F649-F655

10. Zhou XP, Hurst RD, Whiteside CI (1995) High glucose alters cytoskeletal F-actin assembly in glomerular mesangial and epithelial cells. Lab Invest 73: 372-383

11. Zhou XP, Li C, Dlugosz J, Kapor-Drezgic J, Munk S, Whiteside C (1997) Mesangial cell actin disassembly in high glucose mediated by protein kinase $\mathrm{C}$ and the polyol pathway. Kidney Int 51: $1797-1808$

12. Kreisberg JI, Venkatachalam M, Troyer D (1985) Contractile properties of cultured glomerular mesangial cells. Am J Physiol 249:F457-F463

13. Hiraoka-Yoshimoto M, Higashida K, Takeda M, Kawamoto S, Ichikawa I, Hoover RL (1991) Characterization of myosin heavy and light chains in cultured mesangial cells. Kidney Int 40: 1013-1019

14. Lee MW, Severson DL (1994) Signal transduction in vascular smooth muscle: diacylglycerol second messengers and PKC action. Am J Physiol 267:C659-C678

15. Choi OH, Adelstein RS, Beaven MA (1994) Secretion from rat basophilic RBL-2H3 cells is associated with diphosphorylation of myosin light chains by myosin light chain kinase as well as phosphorylation by protein kinase C. J Biol Chem 269 (1):536-541

16. Tanaka T, Ohta H, Kanda K, Hidaka H, Sobue K (1990) Phosphorylation of high- $\mathrm{M}_{\mathrm{r}}$ caldesmon by protein kinase- $\mathrm{C}$ modulates the regulatory function of this protein on the interaction between actin and myosin. Eur J Biochem 188: 495-500

17. Inoguchi T, Battan R, Handler E, Sportsman JR, Heath W, King GL (1992) Preferential elevation of protein kinase C isoform $\beta \mathrm{II}$ and diacylglycerol levels in the aorta and heart of diabetic rats: differential reversibility to glycemic control by islet cell transplantation. Proc Natl Acad Sci USA 89: 11059-11063

18. DeRubertis FR, Craven PA (1994) Activation of protein kinase $\mathrm{C}$ in glomerular cells in diabetes. Mechanisms and potential links to the pathogenesis of diabetic glomerulopathy. Diabetes 43: $1-8$

19. Ziyadeh FN (1993) The extracellular matrix in diabetic nephropathy. Am J Kidney Dis 22: 736-744

20. Kreisberg JI (1992) Hyperglycemia and microangiopathy. Direct regulation by glucose of microvascular cells. Lab Invest 67: 416-426

21. Ruderman NB, Williamson JR, Brownlee M (1992) Glucose and diabetic vascular disease. FASEB J 6: 2905-2914
22. Yamaoka T, Nishimura C, Yamashita K et al. (1995) Acute onset of diabetic pathological changes in transgenic mice with human aldose reductase cDNA. Diabetologia 38: 255-261

23. Ayo SH, Radnik R, Garoni JA, Troyer RA, Kreisberg JI (1991) High glucose increases diacylglycerol mass and activates protein kinase $\mathrm{C}$ in mesangial cell cultures. Am J Physiol 261:F571-F577

24. Craven PA, DeRubertis FR (1989) Protein kinase C is activated in glomeruli from streptozotocin diabetic rats. J Clin Invest 83: $1667-1775$

25. Williams B, Schrier RW (1993) Glucose-induced protein kinase $\mathrm{C}$ activity regulates arachidonic acid release and eicosanoid production by cultured glomerular mesangial cells. J Clin Invest 92: 2889-2896

26. Huwiler A, Schulze-Lohoff E, Fabbro D, Pfeilschifter J (1993) Immunocharacterization of protein kinase $C$ isoenzymes in rat kidney glomeruli, and cultured glomerular epithelial and mesangial cells. Exp Nephrol 1: 19-25

27. Haller H, Baur E, Quass P et al. (1995) High glucose concentrations and protein kinase $\mathrm{C}$ isoforms in vascular smooth muscle cells. Kidney Int 47: 1057-1067

28. Kikkawa R, Haneda M, Uzu T, Koya D, Sugimoto T, Shigeta Y (1994) Translocation of protein kinase $\mathrm{C} \alpha$ and $\zeta$ in rat glomerular mesangial cells cultured under high glucose conditions. Diabetologia 37: 838-841

29. Preiss J, Loomis CR, Bishop WR, Stein R, Niedel, Bell RM (1986) Quantitative measurement of sn-1,2-diacylglycerols present in platelets, hepatocytes, and ras- and sis-transformed normal rat kidney cells. J Biol Chem 261(19):8597-8600

30. Heasley LE, Johnson GL (1989) Regulation of protein kinase $\mathrm{C}$ by nerve growth factor, epidermal growth factor, and phorbol esters in PC12 pheochromocytoma cells. J Biol Chem 264 (15):8646-8652

31. Dvornik D (1987) Hyperglycemia in the pathogenesis of diabetic complications. In: Porte D (ed) Aldose reductase inhibition: an approach to the prevention of diabetic complications. McGraw Hill, New York, pp 69-151

32. Yagihashi S, Kamijo M, Ido Y, Mirrlees DJ (1990) Effects of long-term aldose reductase inhibition on development of experimental diabetic neuropathy: ultrastructural and morphometric studies of sural nerve in streptozotocin-induced diabetic rats. Diabetes 39: 690-696

33. Bank N, Mower P, Aynedjian HS, Wilkes BM, Silverman S (1989) Sorbinil prevents glomerular hyperperfusion in diabetic rats. Am J Physiol 256:F1000-F1006

34. Forster HG, Wee PM, Takenaka T, Hohman TC, Epstein M (1994) Impairment of afferent arteriolar myogenic responsiveness in the galactose-fed rat. Proc Soc Exp Biol Med 206(4):365-374

35. Donnelly S, Zhou XP, Huang J, Whiteside CI (1996) Prevention of early glomerulopathy with tolrestat in the streptozotocin-induced diabetic rat. Biochem Cell Biol 74(3):355-362

36. Miralem T, Wang A, Whiteside C I, Templeton DM (1996) Heparin inhibits mitogen-activated protein kinase-dependent and -indepedent c-fos induction in mesangial cells. J Biol Chem 271: 17100-17106

37. Larkins RG, Dunlop ME (1992) The link between hyperglycemia and diabetic nephropathy. Diabetologia 35: 499-504

38. Moolenar WH (1995) Lysophosphatidic acid, a multifunctional phospholipid messenger. J Biol Chem 270: 12949-12952

39. Kimura K, Ito M, Amano M et al. (1996) Regulation of myosin phosphatase by Rho and Rho-associated kinase. Science 273: 245-248

40. Craven PA, Patterson MC, DeRubertis FR (1988) Role of enhanced arachidonate availability through phospholipase $A_{2}$ pathway in mediation of increased prostaglandin synthesis by glomeruli from diabetic rats. Diabetes 37: 429-435

41. Trachtman H, Futterweit S, Crimmins DL (1997) High glucose inhibits nitric oxide production in cultured rat mesangial cells. J Am Soc Nephrol 8: 1276-1283 